\title{
Occurrence of Mycobacterium avium subsp. paratuberculosis in coalho cheese in the State of Pernambuco, Brazil
}

\author{
[Ocorrência de Mycobaterium avium subsp. paratuberculosis em \\ queijo coalho do Estado de Pernambuco, Brasil] \\ P.P.F. Albuquerque ${ }^{1}$, R.D.S. Cezar ${ }^{2}$, J.W. Pinheiro Junior ${ }^{1}$, \\ G. Grazielle Nascimento ${ }^{3}$, A.S. Santos ${ }^{3}$, R.A. Mota ${ }^{1}$ \\ ${ }^{1}$ Universidade Federal Rural de Pernambuco - Recife, PE \\ ${ }^{2}$ Centro Universitário Maurício de Nassau - Recife, PE \\ ${ }^{3}$ Centro Universitário Brasileiro - Recife, PE
}

\begin{abstract}
Paratuberculosis is a chronic and incurable disease that affects ruminants and other domestic animals. It is caused by Mycobacterium avium subsp. paratuberculosis (MAP) that may also be involved in some human diseases such as Crohn's disease, type 1 diabetes, sarcoidosis, multiple sclerosis, and Hashimoto's thyroiditis. The objective of this study was to investigate the occurrence of MAP DNA in samples of artisanal coalho cheese purchased in the State of Pernambuco. Forty samples of coalho cheese submitted to the Real Time Polymerase Chain Reaction (qPCR) technique were analyzed for the detection of the MAP region IS900. 11 (27.5\%) were positive with a mean of 195.9 MAP colony forming unit (CFU) per gram of each sample, with a minimum of $30.3 \mathrm{CFU} / \mathrm{g}$ and a maximum of $324.2 \mathrm{CFU} / \mathrm{g}$. Thus, this type of cheese that is one of the most consumed in this region of Brazil constitutes a source of human exposure to MAP. Further research in this area should be performed to evaluate the viability of the bacteria in this cheese type.
\end{abstract}

Keywords: bovine, IS900, qPCR, paratuberculosis

\section{RESUMO}

Paratuberculose é uma enfermidade crônica e incurável que acomete ruminantes e outras espécies de animais domésticos. É causada pelo Mycobacterium avium subsp. paratuberculosis (MAP) e ainda há a suspeita do seu envolvimento em enfermidades nos humanos como a doença de Crohn, diabetes tipo 1, sarcoidose, esclerose múltipla e tireoidite de Hashimoto. Objetivou-se com esta pesquisa investigar a ocorrência do DNA de MAP em amostras de queijo coalho artesanal adquiridas em estabelecimentos comerciais do Estado de Pernambuco. 40 amostras de queijo coalho artesanal foram submetidas a técnica de Reação em Cadeia da Polimerase em Tempo Real (qPCR) para detecção da região IS900 do MAP. 11 (27,5\%) foram positivas com uma média de 195,9 unidades formadoras de colônia (UFC) de MAP por grama de queijo, com detecção mínima de 30,3UFC/g e máxima de 324,2UFC/g. Sendo assim, esse tipo de queijo que é um dos mais consumidos nesta região do Brasil constitui uma fonte de exposição humana ao MAP. Mais pesquisas nessa área devem ser realizadas para avaliar a viabilidade dessa bactéria no queijo coalho.

Palavras-chave: bovino, IS900, qPCR, paratuberculose

\section{INTRODUCTION}

Paratuberculosis is an insidious disease that mainly affects domestic and wild ruminants and is caused by Mycobacterium avium subsp. paratuberculosis (MAP) (Kennedy and

Recebido em 8 de maio de 2018

Aceito em 15 de abril de 2019

E-mail: ppfalbuquerque@gmail.com
Benedictus, 2001). It is suspected that in humans, MAP may be associated with the development of some diseases, since human exposure to MAP has been identified as a potential risk factor for individuals genetically susceptible to Crohn's disease (Sechi and Dow, 2015). It has also been suspected that MAP may be involved in other 
important human diseases such as sarcoidosis (Brownell et al., 2011), Blau's syndrome (Dow and Ellingson, 2010), Hashimoto's thyroiditis (Sisto et al., 2010), multiple sclerosis (Cossu et al., 2011) and type 1 diabetes (Rani et al., 2010).

This bacterium has been reported in various types of food, such as meat, pasteurized milk, infant formula and cheese (Waddell et al., 2016). Due to the suspicion of MAP involvement in Crohn's disease, milk and its by-products received greater attention as a source of MAP infection for humans because they are considered to be possible carriers of this bacterium from the animal to the human (Corti and Stephan, 2002). The microorganism can be shed in the milk of infected animals, or even because raw milk can also be contaminated with fecal material containing MAP (Stabel et al., 2002; Donaghy et al., 2011).

In the northeastern region of Brazil, artisanal coalho cheese is a very popular product characterized by being a white pastry cheese with a rectangular shape and slightly acid and salty taste. Coalho cheese can be produced in considerable quantity from raw milk, which, if it is not properly hygienic, may not present microbiological safety or standardization (Almeida et al., 2013; Feitosa et al., 2003). In the State of Pernambuco, paratuberculosis has been reported in some studies involving cattle (Mota et al., 2007; Sá et al., 2013) and buffaloes (Mota et al., 2010) in dairy farms. The presence of DNA has also been detected in milk samples of cows from several properties in the same State (Albuquerque et al., 2017). Considering the risk of consumption of milk derivatives as a risk for human infection by MAP, the objective of this study was to investigate the occurrence of MAP DNA in coalho cheese samples from Pernambuco, Brazil.

\section{METHODOLOGY}

Forty samples of artisanal coalho cheese purchased in commercial establishments such as bakeries, supermarkets and public markets from Garanhuns microregion, Pernambuco, Brazil, were analyzed. The samples were sent to the laboratory in a Styrofoam box containing recyclable ice in the day of collection in their original packaging. To perform DNA extraction, $10 \mathrm{~g}$ of cheese were weighed and macerated in
$20 \mathrm{ml}$ of sterile $0.9 \%$ saline solution in a sterile bag. DNA extractions were performed with $20 \mathrm{mg}$ of the macerated material using the commercial Wizard SV Genomic DNA Purification System kit (Promega) following the manufacturer's instructions.

After DNA extractions, the Real-Time Polymerase Chain Reaction (qPCR) was performed as described by Albuquerque et al. (2017). It consisted of a reaction final volume of $25.0 \mu \mathrm{L}$ containing: $5 \mu \mathrm{L}$ of genomic DNA; $1 \mu \mathrm{L}$ of the specific primers for IS900 at $10 \mu \mathrm{M}$ (DF: 5'-GACGACTCGACCGCTAATTG-3 'and DR1: 5'-CCGTAACCGTCATTGTCCAG-3') (Taddei et al., 2008); 5.5 $\mu \mathrm{L}$ of ultra-pure mili-Q Water and $12.5 \mu \mathrm{L}$ of QuantiFast SYBR Green PCR Kit (QIAGEN® PCR mix) according to manufacturer instructions. The thermal profile of the reaction stages was performed in a RotorGene Q Thermal Cycler (QIAGEN) with initial denaturation at $95^{\circ} \mathrm{C}$ for 5 minutes, followed by 45 cycles at $95^{\circ} \mathrm{C}$ for 20 seconds and $60^{\circ} \mathrm{C}$ for 30 seconds. The software "Rotor-Gene Q Software v1.7" was used to monitor and interpret the qPCR results.

The DNA of a MAP strain provided by the National Agricultural Laboratory of Minas Gerais identified as "Nakajima1991" was used to standardize the reaction. The melting curve consisted of $65^{\circ} \mathrm{C}$ for 90 seconds for the preparation, with posterior gradual increase of $0.1^{\circ} \mathrm{C}$ every 2 seconds from $75^{\circ}$ to $90^{\circ} \mathrm{C}$. The number of copies of the fragment was determined using methodology described by Rodríguez-Lázaro et al. (2005). The number of copies detected was divided by 15 , which corresponds to the average copies of the IS900 region found in the MAP genome (Kralik et al., 2011). The MAP DNA was 10-fold serially diluted and used to obtain the standard curve, in which it was possible to detect from 21 up to 2.12 x 107 MAP cells. The efficiency of the primers was $100 \%$ and the coefficient of linear correlation $\left(\mathrm{R}^{2}\right)$ was 0.999850 . The threshold value was between 9.46 and 26.43 with the denaturation peak at $83.4^{\circ} \mathrm{C}$. Reactions were made in duplicates. Finally, the copy numbers from the positive samples were quantified using the standard curve obtained as reference.

To verify the presence of inhibitors in the samples, some cheese samples of $120 \mathrm{ng} / \mu \mathrm{L}$ were 
randomly selected and diluted to $100,80,40$ and $20 \mathrm{ng} / \mu \mathrm{L}$ of DNA. Then, 20ng of positive control were added to the diluted samples and qPCR was performed. All dilutions had the same $\mathrm{Cq}$ in the qPCR; therefore, there were no inhibitors in the samples. To validate the amplifications, four of the positive samples in qPCR for the IS900 region of the MAP were sent for sequencing. Samples were bidirectionally sequenced using standard protocol using the BigDye Terminator v3.1 Cycle Sequencing Kit (Applied Biosystems) in an automated ABI-PRISM 3130 sequencer (Applied Biosystems). Sequences were analyzed using the Basic Local Align Sequence Tool (BLAST; www.blast.ncbi.nlm.nih.gov/Blast.cgi) platform. This study was approved by the Ethics Committee for the Use of Animals of the Federal Rural University of Pernambuco under license no. 123/2015. The authors declare no potential conflicts of interest with respect to this study or the authorship and/or publication of this article.

\section{RESULTS}

Of the 40 cheese samples analyzed, 11 (27.5\%) were positive for the IS900 region of MAP in the qPCR. In the quantification of these samples it was possible to determine an average of 195.9 MAP colony forming unit (CFU) per gram of each sample, with a minimum of $30.3 \mathrm{CFU} / \mathrm{g}$ and a maximum of $324.2 \mathrm{CFU} / \mathrm{g}$ (Figure 1). The sequencing result of the four samples exhibited a similarity ranging from $96 \%$ to $98 \%$ with the MAP sequence deposited in BLAST (MAP4 Complete Genome).
Detection of IS900 MAP Region in Coalho Cheese

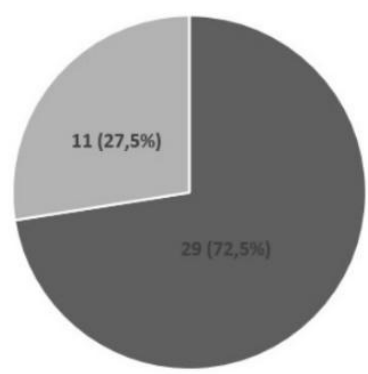

A

Negative = Positive

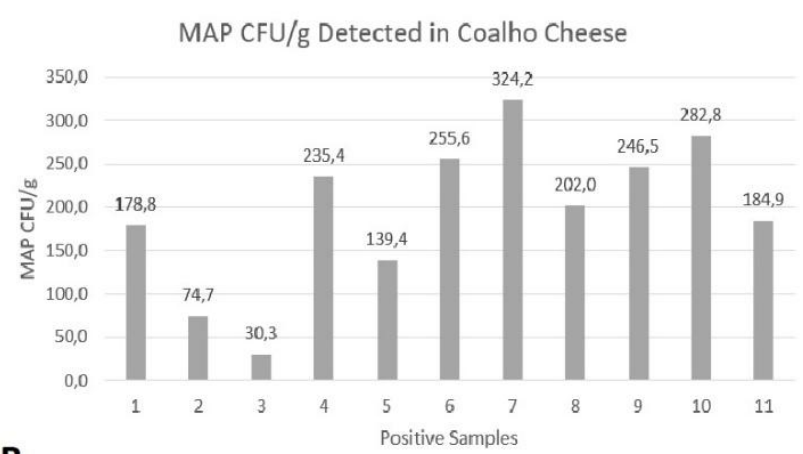

$B$

Figure 1. A - Positive samples for the IS900 MAP DNA region; B - Quantification of MAP UFC in each positive cheese sample.

\section{DISCUSSION}

The coalho cheese is a very consumed product and is part of the culture of the Northeast Region. Its manufacturing process is governed by state law, and raw fresh whole milk can be used in the artisanal confectionery of this cheese (Pernambuco, 2018). However, the use of milk without heat treatment may endanger the health of the consumer (Dias et al., 2015). The presence of MAP in cheeses has been previously reported in some studies worldwide (Botsaris et al., 2010; Williams and Withers, 2010). In Brazil, bacterial DNA was also detected in samples of coalho cheese in the State of Piauí by the PCR technique to detect the MAP region IS900, resulting in 3 (10\%) positive samples (Faria et al., 2014).

In our study, a higher occurrence of MAP DNA was observed in coalho type cheese samples, perhaps due to the influence of the area where these samples were collected. In the state of Pernambuco, paratuberculosis has been reported with a certain frequency in cattle (Mota et al., 2007; Sá et al., 2013), and its DNA was detected in milk samples in the Garanhuns microregion (Albuquerque et al., 2017). It is also important to highlight that the qPCR technique used in our study has a greater sensitivity and specificity in the detection of this microorganism when compared to conventional PCR, and also has the capacity to quantify the bacteria (Mackay, 2004).

An earlier study by Albuquerque et al. (2017) in dairy herds from the Garanhuns microregion where some outbreaks of paratuberculosis were detected, an average of 160CFU/ml MAP was quantified in milk samples from positive cows. In this study, the number of CFU/g was higher (mean of $195.9 \mathrm{CFU} / \mathrm{g}$ ), and may be justified by 
the fact that the transformation of milk in to cheese basically consists of a process that concentrates a great amount of milk, in which part of the solid components, mainly protein and fat are concentrated in the curd, while the whey proteins, lactose and soluble solids are removed in the whey (Paula et al., 2009). And also, a study that developed an efficient procedure for isolation of MAP from raw and heat treated milk detected higher amount of $\mathrm{CFU}$ in the cream milk portion (Gao et al., 2005).

Experimentally, it has been verified that this mycobacterium can survive thermal processes that simulate pasteurization (Sung and Collins, 1998). And, an experimental study has reported that MAP microorganisms isolated from patients with Crohn's disease presented greater thermal resistance when compared to animal isolates (Chiodini and Hermon-Taylor, 1993). The coalho cheese has a $\mathrm{pH}$ around 5.35 and a salt concentration ranging from $0.8 \%$ to $1 \%$ (Sena et al., 2000) and a problem in the manufacture of this artisanal cheese is that the milk used does not need to undergo a heat treatment (Almeida et al., 2013). These intrinsic characteristics favor MAP survival time in cheese (Sung and Collins, 2000). In addition, the survival of this microorganism has already been reported in an isolate made from coalho cheese (Faria et al., 2014).

Studies involving risk factors for the development of Crohn's disease have discordant results, since some did not find an association between the microorganism and the disease in humans and others found an association between the disease and the consumption of meat and processed cheeses (Waddell et al., 2016). However, as animals are the main source of infection, transmission of MAP from infected animals to humans would be the most likely route (Collins, 1997).

While there is no definitive answer regarding the involvement of MAP in diseases in humans, it is important to conduct research to detect this microorganism in food, because if this relationship is confirmed, there will already be epidemiological data that may help in the control, besides, these results can still serve as indicators for possible infected herds in the region from which the samples were collected.

\section{CONCLUSION}

It is concluded that coalho cheese, which is one of the most consumed in this region of Brazil constitutes a source of human exposure to MAP. Further research in this area should be performed to evaluate the viability of the bacteria in this cheese type.

\section{REFERENCES}

ALBUQUERQUE, P.P.F.; SANTOS, A.S.; SOUZA NETO, O.L. et al. Detection of Mycobacterium avium subsp. paratuberculosis in bovine milk from the state of Pernambuco, Brazil. Braz. J. Microbiol., v.48, p.113-117, 2017.

ALMEIDA, S.L.; PAIVA JÚNIOR, F.G.; GUERRA, J.R.F. Representação da produção e consumo do queijo. Rev. Interdisc. Gestão Soc., v.2, p.37-58, 2013.

BOTSARIS, G.; SLANA, I.; LIAPI, M. et al. Rapid detection methods for viable Mycobacterium avium subspecies paratuberculosis in milk and cheese. Int. J. Food Microbiol., v.141, p.87-90, 2010.

BROWNELL, I.; RAMIŔEZ-VALLE, F.; SANCHEZ, M. et al. Evidence for mycobacteria in sarcoidosis. Am. J. Respi.r Cell Mol. Biol., v.45, p.899-905, 2011.

CHIODINI, R.J.; HERMON-TAYLOR, J. The thermal resistance of Mycobacterium paratuberculosis in raw milk under conditions simulating pasteurization. J. Vet. Diagn. Invest., v.5, p.629-631, 1993.

COLLINS, M.T. Mycobacterium paratuberculosis: a potential food-borne pathogen? J. Dairy Sci., v.80, p.3445-3448, 1997.

CORTI, S.; STEPHAN, R. Detection of Mycobacterium avium subspecies paratuberculosis specific IS900 insertion sequences in bulk-tank milk samples obtained from different regions throughout Switzerland. BMC Microbiol., v.2, p.15, 2002.

COSSU, D.; COCCO, E.; PACCAGNINI, D. et al. Association of Mycobacterium avium subsp. paratuberculosis with multiple sclerosis in sardinian patients. PLOS ONE, v.6, p.2-7, 2011.

DIAS, J.N.; LIMA, F.L.; MACHADO, S.M.O. et al. Avaliação das condições higiênico-sanitárias de leite cru e queijo coalho. Ver. Saude Pública, v.8, p.277284,2015

DONAGHY, J.A.; JOHNSTON, J.; AND ROWE, M.T. Detection of Mycobacterium avium ssp. paratuberculosis in cheese, milk powder and milk using IS900 and f57-based qPCR assays. J. Appl. Microbiol., v.110, p.479-489, 2011. 
DOW, C.T.; ELLINGSON, J.L.E. Detection of Mycobacterium avium ss. Paratuberculosis in blau syndrome tissues. Autoimmune Dis., 2010, p.1-5, 2010.

FARIA, A.C.S.; SCHWARZ, D.G.G.; CARVALHO, I.A. et al. Short communication: viable Mycobacterium avium subspecies paratuberculosis in retail artisanal coalho cheese from Northeastern Brazil. J. Dairy Sci., v.97, p.4111-4114, 2014.

FEITOSA, T.; BORGES, M. F.; NASSUI, R.T. et al Pesquisa de Salmonella sp., Listeria sp. e microrganismos indicadores higiênico-sanitários em queijos produzidos no estado do Rio Grande do Norte. Ciênc. Tecnol. Aliment., v.23, p.162-165, 2003.

GAO, A.; ODUMERU, J.; RAYMOND, M. et al. Development of improved method for isolation of Mycobacterium avium subsp. paratuberculosis from bulk tank milk: effect of age of milk, centrifugation, and decontamination. Can. J. Vet. Res., v.69, p.81-87, 2005.

KENNEDY, D.J.; BENEDICTUS, G. Control of Mycobacterium avium subsp. paratuberculosis infection in agricultural species. Rev. Sci. Tech., v.20, p.151-179, 2001

KRALIK, P.; SLANA, I.; KRALOVA, A. et al. Development of a predictive model for detection of Mycobacterium avium subsp. paratuberculosis in faeces by quantitative real time PCR. Vet. Microbiol., v.149, p.133-138, 2011.

MACKAY, I.M. Real-time PCR in the microbiology laboratory. Clin Microbiol Infect., v.10, n.3, p. 190$212,2004$.

MOTA, R.; PINHEIRO JUNIOR, J.; GOMES, M. et al. Paratuberculose em um Rebanho Bovino Leiteiro no Estado de Pernambuco, PE. Arq. Inst. Biol., v.74, p.73-79, 2007.

MOTA, R.A.; PEIXOTO, P.V.; YAMASAKI, E.M. et al. Ocorrência de paratuberculose em búfalos (Bubalus bubalis) em Pernambuco. Pesqui. Vet. Bras., v.30, p.237-242, 2010.

PAULA, J.C.J.; CARVALHO, A.F.; FURTADO, M.M. Princípios básicos de fabricação de queijo: do histórico à saga. Rev. Inst. Latic. Candido Tostes, v.64, p.19-25, 2009.

PERNAMBUCO. Lei ${ }^{\circ} 16.312$, de 11 de janeiro de 2018, dispõe sobre processo de Produção do Queijo Artesanal e dá outras providências, a fim de incluir o queijo de manteiga, a manteiga de garrafa e o doce de leite no processo de produção artesanal. 2018.
RANI, P.S.; SECHI, L.A.; AHMED, N. Mycobacterium avium subsp. paratuberculosis as a trigger of type-1 diabetes: destination Sardinia, or beyond? Gut Pathog., v.2, p.1-6, 2010.

RODRÍGUEZ-LÁZARO, D.; D’AGOSTINO, M.; HERREWEGH, A. et al. Real-time PCR-based methods for detection of Mycobacterium avium subsp. paratuberculosis in water and milk. Int. J. Food Microbiol., v.101, p.93-104, 2005.

SÁ, L.D.M.; OLIVEIRA, J.M.B.; SANTOS, G.R. et al. Avaliação sorológica e de fatores de risco para a infecção por Mycobacterium avium subsp. paratuberculosis em rebanhos Pesqui. Vet. Bras., v.33, p.310-313, 2013.

SECHI, L.A.; DOW, C.T. Mycobacterium avium ss. paratuberculosis Zoonosis - the hundred year war beyond crohn's disease. Front Immunol., v.6, p.1-8, 2015.

SENA, M.J.; CERQUEIRA, M.M.O.P.; MORAIS, C.F.A. et al. Características físico-químicas de queijo de coalho comercializado em Recife, PE. Hig. Aliment, v.14, p.41-44, 2000.

SISTO, M.; CUCCI, L.; D'AMORE, M. et al. Proposing a relationship between Mycobacterium avium subspecies paratuberculosis infection and Hashimoto's thyroiditis. Scand. J. Infect. Dis., v.42, p.787-790, 2010.

STABEL, J.R.; WELLS, S.J.; WAGNER, B.A. Relationships between fecal culture, ELISA, and bulk tank milk test results for Johne's disease in US dairy herds. J. Dairy Sci., v.85, p.525-531, 2002.

SUNG, N.; COLLINS, M.T. Effect of three factors in cheese production ( $\mathrm{pH}$, Salt, and Heat) on Mycobacterium avium subsp. paratuberculosis viability. Appl. Environ. Microbiol., v.66, p.13341339, 2000.

SUNG, N.; COLLINS, M.T. Thermal tolerance of Mycobacterium paratuberculosis. Appl. Environ. Microbiol., v.64, p.999-1005, 1998.

TADDEI, R.; BARBIERI, I.; PACCIARINI, M, L. Mycobacterium porcinum strains isolated from bovine bulk milk: implications for Mycobacterium avium subsp. paratuberculosis detection by PCR and culture. Vet. Microbiol., v.130, p.338-347, 2008.

WADDELL, L.; RAJIĆ, A.; STÄRK, K. et al. Mycobacterium avium ssp. paratuberculosis detection in animals, food, water and other sources or vehicles of human exposure: a scoping review of the existing evidence. Prev. Vet. Med., v.132, p.32-48, 2016.

WILLIAMS, A.G.; WITHERS, S.E. Microbiological characterisation of artisanal farmhouse cheeses manufactured in Scotland. Int. J. Dairy Technol., v.63, p.356-369, 2010. 